\title{
ANTIBACTERIAL EFFECTS OF 0.1\% CHLORINE DIOXIDE ON ACTINOMYCES SP. AS AN AGENT OF BLACK STAIN
}

\author{
MARIA CLARISSA EUNIKE, EVA FAUZIAH*, MARGARETHA SUHARSINI
}

Department of Pediatric Dentistry, Faculty of Dentistry, Universitas Indonesia, Jakarta, Indonesia. Email: eva_dens@yahoo.com

Received: 16 September 2017, Revised and Accepted: 3 October 2017

ABSTRACT

Objective: This study aimed to assess the antibacterial effects of $0.1 \%$ chlorine dioxide and $0.1 \%$ chlorhexidine mouthrinses on the bacterial viability of Actinomyces sp. as an agent of black stain.

Methods: The authors conducted a clinical trial involving 16 children ages 6-11 with at least 8 black-stained teeth. Subjects were randomized into 2 groups and instructed to rinse with chlorine dioxide or chlorhexidine mouthrinse twice daily. At baseline and after 7 days, samples of black stain plaque were collected, and Actinomyces sp. was cultured. Its bacterial viability was evaluated using an 3-(4,5-dimethylthiazol-2-yl)-2,5-diphenyl-2Htetrazolium bromide assay.

Results: After 7 days, Actinomyces sp. viability was remarkably reduced in both groups, and there was a significantly higher reduction in viability in the $0.1 \%$ chlorine dioxide group than there was in the $0.1 \%$ chlorhexidine group.

Conclusion: Mouthrinse containing $0.1 \%$ chlorine dioxide has a greater antibacterial effect against Actinomyces sp. than mouthrinse containing $0.1 \%$ chlorhexidine.

Keywords: Actinomyces sp., Black stain, Bacterial viability, Chlorine dioxide, Chlorhexidine.

(C) 2017 The Authors. Published by Innovare Academic Sciences Pvt Ltd. This is an open access article under the CC BY license (http://creativecommons. org/licenses/by/4. 0/) DOI: http://dx.doi.org/10.22159/ijap.2017.v9s2.19

\section{INTRODUCTION}

Dental black stain is a type of extrinsic discoloration that can affect deciduous and permanent teeth. The clinical diagnosis of dental black stain is based on the presence of pigmented dark lines that run parallel to the gingival margin, rarely extending beyond the cervical-third of the tooth crown $\left[{ }^{*} 1,2\right]$.

The prevalence of black stain varies by age, population, and country. In Europe, the prevalence of black stain varies from 2\% (Great Britain) to 4\% (Poland), 6\% (Italy), and 7\% (Valencia, Spain). In South America, the prevalence ranges from 6\% (Peru) to $15 \%$ (Brazil). On the Asian continent, it varies from 16\% (Philippines) to $18 \%$ (India) [3,4]. In Indonesia, the prevalence of black stain is approximately $5 \%$ [5].

The etiology factors of black stain are not fully understood, although certain types of bacteria seem to be involved [6]. The previous studies have reported a relationship between black stain and chromogenic bacteria such as Actinomyces sp. and Prevotella melaninogenica. The majority of bacteria (90\%) that can be isolated from black stain are facultative aerobic and anaerobic Gram-positive rods, which are identified as Actinomyces sp. [6,7].

Black stain tends to recur despite good personal oral hygiene but less may grow when biofilm control procedures are performed meticulously [7]. *Antibacterial mouthrinse has been considered an effective method of controlling dental plaque [8]. Evidence in the dental literature supports chlorhexidine as the gold standard of biofilmpreventing antiplaque and antigingivitis agents [9]. However, regardless of chlorhexidine potent antimicrobial properties, local side effects such as tooth staining restrict how long each patient can use it $[9,10]$. Since there is no significant difference between the antimicrobial efficacy of $0.1 \%$ and $0.2 \%$ chlorhexidine, dentists recommend mouthrinses with the lower concentration $(0.1 \%)$ [11].
Chlorine dioxide has been widely used in various fields because it is safe and has strong antibacterial properties $\left[12,13^{* *}\right]$. *In dentistry, chlorine dioxide has been used in the treatment of oral, and especially periodontal diseases [14]. The main advantages of this product are that it is non-staining, alcohol-free, and non-irritating, that it does not cause taste alteration, and that it is free of sodium lauryl sulfate [15]. Chlorine dioxide mouthrinses have been widely used in developed countries such as Japan and North America [12]. A previous study suggests that $0.1 \%$ chlorine dioxide is effective as an antibacterial agent and does not cause side effects, such as a reduced sense of taste or tooth discoloration [16].

Studies that focus on the black stain and its treatment are rarely found in the dental literature [6]. The aim of this study was to assess the antibacterial effects of mouthrinses containing either $0.1 \%$ chlorine dioxide or $0.1 \%$ chlorhexidine on the bacterial viability of Actinomyces sp. as an agent of black stain.

\section{METHODS}

\section{Subjects}

The subjects were 16 children aged 6-11 who were recruited from two elementary schools in Jakarta and the Pediatric Dentistry Clinic at the Faculty of Dentistry, Universitas Indonesia. All subjects had at least 8 black-stained teeth (deciduous or permanent), no medical disorders, and deft indices of $\leq 5$. No subjects were undergoing antibiotic or other antimicrobial therapy, and all were able to participate in the experiment. The subjects and their parents received verbal and written information about the study, and the parents of all subjects signed forms giving their consent for their children to participate. Oral examinations were conducted to assess the oral status of the subjects before the experiment. No subjects reported using commercial mouthrinse or antibacterial toothpaste on a regular basis. All dental examinations, both baseline and follow-up, were conducted by a single trained examiner. 
The study design, protocol, and informed consent were approved by the Ethics Committee of the Faculty of Dentistry, Universitas Indonesia. The procedures, possible benefits, and possible discomforts or risks were fully explained to the subjects and the subjects' parents.

\section{Study design}

This study was a randomized, single-blind clinical trial, and laboratory observation. Each subject was randomly assigned to one of 2 groups. The group 1 subjects $(n=8)$ were instructed to rinse with $10 \mathrm{ml}$ of experimental mouthrinse containing $0.1 \%$ chlorine dioxide for 7 days, twice per day (after breakfast and before sleeping) for $30 \mathrm{~s}$ each time. Those in Group $2(n=8)$ were instructed to rinse in the same way with a mouthrinse containing $0.1 \%$ chlorhexidine.

At baseline and after 7 days, samples of black stain plaque were collected from the subjects into sterile Eppendorf tubes using new metal excavators. All samples were placed on ice before being immediately sent to the Oral Biology Laboratorium at the Faculty of Dentistr y, Universitas Indonesia.

\section{Actinomyces sp. colonization and identification}

Brain heart infusion (BHI) broth $(1 \mathrm{ml})$ was added to the Eppendorf tubes containing samples of black stain plaque. The contents of each Eppendorf tube were homogenized using a vortex mixer, and $20 \mu \mathrm{l}$ of the bacterial suspension were transferredto Actinomyces agar, used as a selective medium for Actinomyces sp. The agar plate was placed inside an anaerobic jar (containing $80 \% \mathrm{~N}_{2}, 10 \% \mathrm{H}_{2}$, and $10 \% \mathrm{CO}_{2}$ ) and incubated for $48 \mathrm{~h}$ at $37^{\circ} \mathrm{C}$. The identification of the Actinomyces sp. culture was done by visual inspection and the Gram staining procedure.

Viability test using an 3-(4,5-dimethylthiazol-2-yl)-2,5-diphenyl2H-tetrazolium bromide (MTT) assay

One loopful of the identified Actinomyces sp. colony was transferred to fresh BHI broth. The broth was homogenized using a vortex mixer, and $200 \mu \mathrm{l}$ of the bacterial suspension were transferred to each well of a 96-well microplate. The microplate was placed inside an anaerobic jar (containing $80 \% \mathrm{~N}_{2}, 10 \% \mathrm{H}_{2}$, and $10 \% \mathrm{CO}_{2}$ ) and incubated for $24 \mathrm{~h}$ at $37^{\circ} \mathrm{C}$.

Each well was washed with phosphate-buffered saline solution, and $50 \mu \mathrm{l} 5 \mathrm{mg} / \mathrm{ml}$ of MTT solution were added. The microplate was again placed inside the anaerobic jar (containing 80\% $\mathrm{N}_{2}, 10 \% \mathrm{H}_{2}$, and $10 \% \mathrm{CO}_{2}$ ) and incubated for $3 \mathrm{~h}$ at $37^{\circ} \mathrm{C}$ while covered with aluminum foil. Acidified isopropanol $(100 \mu \mathrm{l})$ was added to each well, and the microplate was placed on an orbital shaker $(50 \mathrm{rpm})$ for $1 \mathrm{~h}$ at $25^{\circ} \mathrm{C}$ [17]. The optical density (OD) was read using an ELISA reader at a wavelength of $490 \mathrm{~nm}$.

There were no significant differences in any OD measures between the two groups at the baseline measurement.

\section{Statistical analysis}

Paired subjects' t-tests were used to compare Actinomyces sp. bacterial viability (based on OD measures) at baseline and after 7 days of rinsing with the $0.1 \%$ chlorine dioxide and $0.1 \%$ chlorhexidine mouthrinses. Individual subjects' t-tests were used to compare Actinomyces sp. bacterial viability between the two mouthrinses.

\section{RESULTS}

All 16 subjects completed the study. The Actinomyces sp. bacterial viabilities, based on OD measures, are listed in Table 1. At baseline, there were no statistically significant differences in Actinomyces sp. bacterial viability (OD measures) between the two groups. After 7 days of rinsing, there were statistically significant differences compared with baseline in Actinomyces sp. bacterial viability in both the chlorine dioxide and the chlorhexidine groups, with $\mathrm{p}=0.001$ and $\mathrm{p}=0.010$ $(\mathrm{p}<0.05)$, respectively.

The mean value differences in Actinomyces sp. bacterial viability between the two mouthrinses, based on OD measures, are listed in Table 2. Statistically significant differences between the two mouthrinses were found, with $\mathrm{p}=0.012 \quad(\mathrm{p}<0.05)$. A statistically significantly greater reduction in Actinomyces sp. bacterial viability was found in the chlorine dioxide group after 7 days compared to that found in the chlorhexidine group after the same period.

\section{DISCUSSION}

This was a preliminary study on finding alternative treatments for preventing black stain recurrence in children. Recurrence is caused by ferric sulfide precipitation, and the study aimed to prevent it by reducing Actinomyces sp. viability as one of the etiological factors of black stain. In this randomized clinical trial, two mouthrinses were compared, one containing chlorine dioxide and the other containing chlorhexidine.

The antibacterial agent used in this study was a commercially available $0.1 \%$ chlorine dioxide mouthrinse (Oxyfresh, Oxyfresh Worldwide Inc., Idaho, USA). Research reports that chlorine dioxide-based mouthrinse is a proven bactericidal agent against bacterial pathogens that cause periodontitis, for example, Aggregatibacter actinomycetemcomitans, Fusobacterium nucleatum, Porphyromonas gingivalis, and Prevotella intermedia [17-19]. This research concludes that chlorine dioxide gel effectively kills the Gram-positive bacteria Streptococcus mitis and Streptococcus constellatus [18]. Until now, however, there has been a limited study of the effectiveness of chlorine dioxide against the Grampositive bacteria Actinomyces sp., especially in association with black stain. Black stain treatment is currently done by scaling and selective polishing, but the recurrence rate is high enough to cause esthetic problems $[8,9]$.

The age range selected for the subjects was 6-11 years, which is the period of mixed dentition. Children in this age range are also able to rinse and follow oral hygiene instructions. The literature states that black stain is quite common in children and can be found in both deciduous and permanent teeth $\left[6,18^{* *}\right]$. In accordance with the enamel surface properties of deciduous teeth, i.e., higher permeability and porosity levels than permanent teeth, the black stain is often found in primary teeth [5].

Of the 147 children examined, 16 had black stain and were then divided randomly into 2 groups. The first group consisted of 8 children, who were given a $0.1 \%$ chlorine dioxide mouthrinse for 7 days. The second group also consisted of 8 children, who were given a $0.1 \%$ chlorhexidine

Table 1: Comparison of the mean values of Actinomyces sp. bacterial viability at baseline and after 7 days of rinsing

\begin{tabular}{lllll}
\hline Mouthrinses & $\mathbf{n}$ & Mean \pm SD & p \\
\cline { 2 - 3 } & & $\begin{array}{l}\text { Bacterial } \\
\text { viability (OD) } \\
\text { baseline }\end{array}$ & $\begin{array}{l}\text { Bacterial } \\
\text { viability (OD) } \\
\mathbf{7} \text { days after }\end{array}$ & \\
\hline $\begin{array}{l}\text { Chlorine } \\
\text { dioxide }(0.1 \%)\end{array}$ & 8 & $0.73 \pm 0.11$ & $0.40 \pm 0.21$ & 0.001 \\
Chlorhexidine $(0.1 \%)$ & 8 & $0.67 \pm 0.18$ & $0.54 \pm 0.09$ & 0.010
\end{tabular}

Paired subjects' t-tests; significance level based on $\mathrm{p}<0.05$. SD: Standard diviation, OD: Optical density

Table 2: Comparison of the mean value differences in Actinomyces sp. bacterial viability between the two mouthrinses

\begin{tabular}{llll}
\hline Mouthrinses & $\mathbf{n}$ & $\begin{array}{l}\boldsymbol{\Delta} \text { bacterial viability (OD) } \\
\text { mean } \pm \text { SD }\end{array}$ & $\mathbf{p}$ \\
\hline Chlorine dioxide $(0.1 \%)$ & 8 & $0.33 \pm 0.17$ & 0.012 \\
Chlorhexidine $(0.1 \%)$ & 8 & $0.13 \pm 0.10$ & \\
\hline
\end{tabular}

Individual student's t-test; significance level based on $\mathrm{p}<0.05$. SD: Standard diviation, OD: Optical density 
mouthrinse for 7 days. The rinsing period was determined as 7 days based on a previous study, which showed a decrease in the number of Gram-negative anaerobic bacteria in saliva after 7 days of rinsing with $0.1 \%$ chlorine dioxide [13]. Gram-negative bacteria have complex cell walls, making them more difficult to penetrate with chlorine dioxide [14]. Since the cell walls of Gram-positive bacteria are simpler, chlorine dioxide can easily penetrate the cell walls of Gram-positive bacteria such as Actinomyces sp., and the number of bacteria can be reduced within 7 days.

Subject homogenization was done by choosing subjects who had good oral hygiene, had deft indices of $\leq 5$, and werein the middle-toupper socioeconomic level. The subject selection was conducted in two elementary schools and the Pediatric Dentistry Clinic Universitas Indonesia, serving the middle-to-upper socioeconomic level in Jakarta. Research in China reports that children of higher socioeconomic status are associated with an increased incidence of black stain. The mean value of the deft indices in the black stain group was also significantly lower than that in the group without black stain [2]. An immunological study examining bacterial attachment confirms that a higher number of Actinomyces naeslundii in dental biofilms is associated with low caries rates (low deft index values) [4]. In this study, the gender of the subject was not considered. Only 2 of the 16 subjects were female, and research in China reports no significant relationship between black stain and gender [2].

This study used black stain plaque samples because previous research has proven that the quantity of Actinomyces sp. is more abundant in the plaque samples of children with black stain than in those of children without black stain [18-20]. In this study, dental plaque and black stain were not distinguished from each other because previous research shows that there is no significant difference between the quantity of Actinomyces sp. in dental plaque and that in black stain [20]. Samples were not taken from saliva because the previous studies show that, although the quantity of Actinomyces sp. in the saliva of children with black stain is higher than that in the saliva of children without it, the difference is not statistically significant [5].

Microbiological samples of Actinomyces sp. were taken from black stain plaque according to the inclusion criteria. Samples were taken in the morning within $2-4 \mathrm{~h}$ after tooth brushing in accordance with previous research confirming that relatively stable amounts of Actinomyces sp. can be found in the early stages of plaque formation within $0-6 \mathrm{~h}$ after tooth brushing [21].

Acytotoxicity assay can be used to assess the antibacterial effects of certain substances. The cytotoxicity of a substance can be measured in various ways, one of which is through the decrease in cell viability following its application. The MTT assay has become the

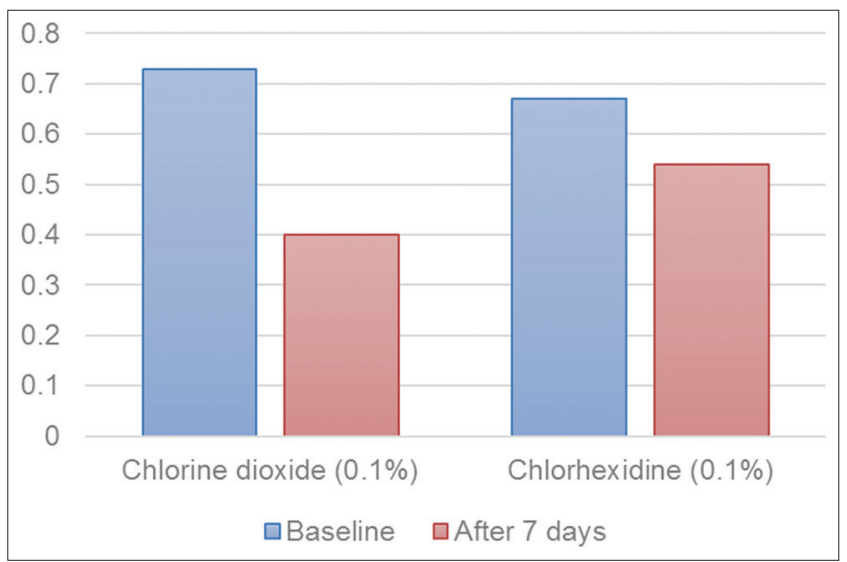

Fig. 1: Comparison of the mean values of Actinomyces sp. bacterial viability at baseline and after 7 days of rinsing preferred method of determining cell viability through the activity of mitochondrial reductase enzymes, expressed by OD. The value of OD is proportional to the number of living cells $[17,22]$.

In this study, the antibacterial properties of $0.1 \%$ chlorine dioxide and $0.1 \%$ chlorhexidine were expressed in the reduction of Actinomyces sp. bacterial viability, based on the value of the OD. Statistical analysis using paired subjects' t-tests, listed in Table 1, resulted in the conclusion that, compared with the baseline, and there were statistically significant differences in Actinomyces sp. bacterial viability in both the chlorine dioxide and chlorhexidine groups after 7 days of rinsing. This result was consistent with the literature, which states that $0.1 \%$ chlorine dioxide and $0.1 \%$ chlorhexidine have strong antibacterial properties and can kill bacteria in the oral cavity $\left[12,13^{* *}\right]$

The previous research suggests that rinsing with a $0.1 \%$ chlorine dioxide mouthrinse for 7 days effectively reduces the number of Gram-positive and Gram-negative anaerobic bacteria in the oral cavity. Another study on the bactericidal activity of chlorine dioxide states that chlorine dioxide mouthrinse can kill up to $90 \%$ of oral pathogens in $<30 \mathrm{~min}$ and that the effect lasts up to $7 \mathrm{~h}\left[13,23^{* *}\right]$.

A statistical analysis using individual subjects' t-tests, which are shown in Table 2, resulted in the conclusion that there was a significant difference between the two mouthrinses. The chlorine dioxide group exhibited a statistically significantly greater reduction in the bacterial viability of Actinomyces sp. than did the chlorhexidine group. It can be concluded that a $0.1 \%$ chlorine dioxide mouthrinse has a stronger antibacterial effect against Actinomyces sp. than a $0.1 \%$ chlorhexidine mouthrinse.

Chlorine dioxide is an antibacterial agent that penetrates the bacterial cell wall and binds to the vital amino acids (cysteine, methionine, tyrosine, and tryptophan) that are essential for microorganisms in the cell wall and bacterial cytoplasm [*13,24-26]. Chlorine dioxide destabilizes the permeability of the bacterial cell membrane, causing the cell wall to rupture [14]. The resulting disturbance of the nutrient transport system through the cell wall will kill the bacterium [25]. Chlorine dioxide also limits the proliferation of anaerobic bacteria through oxygenation and the neutralization of the toxins (bacterial proteolytic enzymes) that bacteria produce in the oral cavity [15].

In vitro studies suggest that chlorine dioxide is less toxic to human gingival cells than chlorhexidine. Chlorine dioxide does not form chlorinated hydrocarbons when in contact with organic compounds, so it is not carcinogenic or allergenic. Study subjects also do not complain of changes in taste after using $0.1 \%$ chlorine dioxide mouthrinse $\left[13,23,24^{* *}\right]$. All of these advantages make chlorine dioxide a safe antibacterial agent that can be used by children.

Chlorhexidine was used in this study because it has been recognized as the gold standard of antibacterial agents. Research conducted in vitro shows that $0.2 \%$ chlorhexidine mouthrinse is effective against the majority of oral bacteria, including Actinomyces viscosus [9]. A 6-month longitudinal study reported increased staining in a group rinsing with chlorhexidine, in comparison with a baseline measurement, and the concentration of chlorhexidine was correlated to stain formation and the intensity of dental discoloration [10]. Research conducted with children aged 10 to 12 reports changes in the patients' sense of taste after 1 week of rinsing with a $0.2 \%$ chlorhexidine mouthrinse [10]. In this study, a mouthrinse containing $0.1 \%$ chlorhexidine was used for a more acceptable effect on taste and a lower potential for stain formation. Chlorhexidine side effects, such as staining over prolonged periods of use and taste alteration, tend to limit the usage of this mouthrinse in children.

\section{CONCLUSIONS}

We can conclude from this study that there are significant differences in Actinomyces sp. bacterial viability after 7 days of rinsing with $0.1 \%$ 
chlorine dioxide and $0.1 \%$ chlorhexidine mouth rinses. These mouth rinses are effective in reducing Actinomyces sp. bacterial viability, which is widely considered an etiological factor of black stain.

We can also conclude that there are significant differences between the two mouthrinses. After 7 days of rinsing, there was a significantly greater reduction in Actinomyces sp. bacterial viability in the chlorine dioxide group than there was in the chlorhexidine group. Therefore, it can be concluded that mouthrinse containing $0.1 \%$ chlorine dioxide has a greater antibacterial effect against Actinomyces sp. than mouthrinse containing $0.1 \%$ chlorhexidine.

\section{ACKNOWLEDGMENTS}

This study was funded by the Directorate of Research and Community Service, Universitas Indonesia, in 2017.

The publication of this manuscript is supported by Universitas Indonesia.

\section{REFERENCES}

1. Bandon D, Chabane-Lemboub A, Le Gall M. Exogenous tooth discoloration in children: Black stains. Arch Pediatr 2011:18:1348-52.

2. Chen X, Zhan JY, Lu HX, Ye W, Zhang W, Yang WJ, et al. Factors associated with black tooth stain in Chinese preschool children. Clin Oral Investig 2014;18:2059-66.

3. Garcia Martin JM, Gonzalez Garcia M, Seoane Leston J, Llorente Pendas S, Diaz Martin JJ, Garcia-Pola MJ. Prevalence of black stain and associated risk factors in preschool Spanish children. Pediatr Int 2013;55:355-9.

4. Heinrich-Weltzien R, Monse B, van Palenstein Helderman W. Black stain and dental caries in Filipino schoolchildren. Community Dent Oral Epidemiol 2009;37:182-7.

5. Rustan Y. Kuantitas Bakteri Actinomyces di Saliva Anak Dengan Black Stain Pada Permukaan Email Gigi. Tesis. Jakarta: Univeristas Indonesia; 2012. p. 22-8.

6. Zyla T, Kawala B, Antoszewska-Smith J, Kawala M. Black stain and dental caries: A review of the literature. Biomed Res Int 2015;2015:469392.

7. Ronay V, Attin T. Black stain-a review. Oral Health Prev Dent 2011;9:37-45

8. Yeturu SK, Acharya S, Urala AS, Pentapati KC. Effect of Aloe vera, chlorine dioxide, and chlorhexidine mouth rinses on plaque and gingivitis: A randomized controlled trial. J Oral Biol Craniofac Res 2016;6:54-8

9. Ronanki S, Kulkarni S, Hemalatha R, Kumar M, Reddy P. Efficacy of commercially available chlorhexidine mouthrinses against specific oral microflora. Indian J Dent Res 2016;27:48-53.

10. Lang NP, Hotz P, Graf H, Geering AH, Saxer UP, Sturzenberger OP, et al. Effects of supervised chlorhexidine mouthrinses in children. A longitudinal clinical trial. J Periodontal Res 1982;17:101-11.

11. Ernst CP, Prockl K, Willershausen B. The effectiveness and side effects of $0.1 \%$ and $0.2 \%$ chlorhexidine mouthrinses: A clinical study. Quintessence Int 1998;29:443-8

12. Shinada K, Ueno M, Konishi C, Takehara S, Yokoyama S, Kawaguchi Y. A randomized double blind crossover placebo-controlled clinical trial to assess the effects of a mouthwash containing chlorine dioxide on oral malodor. Trials 2008;9:71.

13. Shinada K, Ueno M, Konishi C, Takehara S, Yokoyama S, Zaitsu T, et al. Effects of a mouthwash with chlorine dioxide on oral malodor and salivary bacteria: A randomized placebo-controlled 7-day trial. Trials 2010;11:14.

14. Al-bayaty F, Taiyeb-ali T, Abdulla MA, Hashim F. Antibacterial effect of chlorine dioxide and hyaluronate on dental biofilm. Afr J Microbiol Res 2010;4:1525-31.

15. Mani S, Mani A, Saini R. Clinical and microbiological evaluation of chlorine dioxide based mouthwash and toothpaste in periodontitis patients along with combination of nutritional dietary supplement of CoQ10. Int J Exp Dent Sci 2013;2:98-103.

16. Kim JS, Park JW, Kim DJ, Kim YK, Lee JY. Direct effect of chlorine dioxide, zinc chloride and chlorhexidine solution on the gaseous volatile sulfur compounds. Acta Odontol Scand 2014;72:645-50.

17. Suwandi T. Pengembangan potensi antibakteri kelopak bunga Hibiscus sabdariffa L. (Rosela) terhadap Streptoccoccus sanguinis penginduksi gingivitis menuju obat herbal terstandar. Disertasi. Jakarta: Universitas Indonesia; 2012. p. 46, 57-8, 98 .

18. Saba C, Solidani M, Berlutti F, Vestri A, Ottolenghi L, Polimeni A. Black stains in the mixed dentition: A PCR microbiological study of the etiopathogenic bacteria. J Clin Pediatr Dent 2006;30:219-24.

19. Heinrich-Weltzien R, Bartsch B, Eick S. Dental caries and microbiota in children with black stain and non-discoloured dental plaque. Caries Res 2014;48:118-25.

20. Li Y, Zhang Q, Zhang F, Liu R, Liu H, Chen F. Analysis of the microbiota of black stain in the primary dentition. PLoS One 2015;10:1-12.

21. Li J, Helmerhorst EJ, Leone CW, Troxler RF, Yaskell T, Haffajee AD, et al. Identification of early microbial colonizers in human dental biofilm. J Appl Microbiol 2004;97:1311-8.

22. van Tonder $A$, Joubert AM, Cromarty AD. Limitations of the 3-(4,5-dimethylthiazol-2-yl)-2,5-diphenyl-2H-tetrazolium bromide (MTT) assay when compared to three commonly used cell enumeration assays. BMC Res Notes 2015;8:1-10.

23. Saini R. Efficacy of preprocedural mouth rinse containing chlorine dioxide in reduction of viable bacterial count in dental aerosols during ultrasonic scaling: A double-blind, placebo-controlled clinical trial. Dent Hypotheses 2015;6:65-71.

24. Herczegh A, Ghidan A, Friedreich D, Gyurkovics M, Bendo Z Lohinai Z. Effectiveness of a high purity chlorine dioxide solution in eliminating intracanal Enterococcus faecalis biofilm. Acta Microbiol Immunol Hung 2013;60:63-75.

25. Herczegh A, Gyurkovics M, Agababyan H, Ghidan Á, Lohinai Z. Comparing the efficacy of hyper-pure chlorine-dioxide with other oral antiseptics on oral pathogen microorganisms and biofilm in vitro. Acta Microbiol Immunol Hung 2013;60:359-72.

26. Noszticzius Z, Wittmann M, Kály-Kullai K, Beregvári Z, Kiss I, Rosivall $\mathrm{L}$, et al. Chlorine dioxide is a size-selective antimicrobial agent. PLoS One 2013;8:1-10. 